\title{
A new approach to improve knowledge and management of grapevine virus diseases: the PAThOGEN project and course
} \author{
Di Gaspero ${ }^{1}$, Sofia Casarin ${ }^{1}$, Vally Forte ${ }^{1}$, Nadia Bertazzon ${ }^{1}$ \\ ${ }^{1}$ CREA, Centro di Ricerca Viticoltura ed Enologia, Conegliano, Italy \\ ${ }^{2}$ HORTA S.r.l., Piacenza, Italy \\ ${ }^{3}$ USC, Universidade de Santiago de Compostela, Lugo, Spain \\ ${ }^{4}$ IFV, Institut Français de la Vigne et du Vin, Le Grau Du Roi, France \\ ${ }^{5}$ FEUGA, Fundación Empresa - Universidad Gallega, Santiago de Compostela, Spain
}

Elisa Angelini ${ }^{1, *}$, Tiziano Bettati ${ }^{2}$, Vittorio Rossi ${ }^{2}$, Cristina Cabaleiro ${ }^{3}$, Anne-Sophie Spilmont ${ }^{4}$, Daniel Duran ${ }^{5}$, Mattia

\begin{abstract}
Beside the well-known fungal pathologies, grapevine virus diseases are of major importance in grapegrowing areas, also due to the limited knowledge by the professionals of the sector. To face this problem, the PAThOGEN training program was developed, with the aims of: (i) building a high-quality Vocational and Education Training program, (ii) improving the skills of the main actors of the wine sector. The pilot courses were developed in two levels (Basic and Advanced) and made available on a dedicated online platform in 4 languages (French, Italian, Spanish and English). Moreover, two field sessions were organized in each of the 3 partner countries in order to complete the theoretical training. A specific feature of this project was the "demand driven approach" used to conceive the courses. Indeed, a panel of experts and 128 "student-testers" were selected in the 3 countries in the different professional categories to test the training program. $98 \%$ of the testers evaluated the training course as "interesting" or "very interesting". The detailed evaluations allowed us to rework the courses both in terms of content and functionality. The elearning training is now available in the four languages, and the field training is annually organized in France, Italy and Spain.
\end{abstract}

\section{Introduction}

Viticulture and winemaking occur in all the word, but their roots are still in Europe, where Italy, France and Spain together still cover approximately half of total world wine production [1]. Every year grapegrowers face important diseases as downy and powdery mildew, but most of them knows nothing or little about viruses. Unluckily, direct management strategies aimed to control virus diseases do not exist, thus the only possibility is prevention, mainly by means of planting healthy graftlings and spraying insecticides against the vectors [2].

In Europe, the most important and wide spread grapevine virus diseases are fanleaf and leafroll, that can seriously affect grape production in terms of quality and quantity, beside threatening plant development and longevity [3].

To face this problem, five partners worked together to develop the PAThOGEN project, a training program aimed to improve grapevine virus knowledge and management among stakeholders. The partnership gathers one French technical centre (IFV), one Spanish university (USC), one Italian applied research centre (CREA), one Spanish foundation specialized in training and technology transfer (FEUGA) and one Italian SME specialized in the development of informatics tools and in knowledge transfer in the vine sector (HORTA).

The objectives of PAThOGEN are: (i) to develop a high-quality work-based Vocational and Education Training (VET) program, (ii) to develop basic and transversal skills using innovative methods and (iii) to improve the skills of professionals of the wine sector. The long-term perspective of this project is to ensure the economic sustainability and durability of worldwide vineyards by decreasing the impact of virus diseases.

\section{Materials and Methods}

A specific feature of this project was the "demand driven approach" used to conceive the e-learning courses.

\subsection{Development of the courses' contents}

The partners developed an innovative e-learning platform containing two levels of training: basic level (four modules) mainly for growers and nurserymen, and advanced level for technicians and advisors (six modules). The first four modules are common to the two levels. Courses content were redacted by partners IFV, CREA and USC (Table 1).

\footnotetext{
* Corresponding author: elisa.angelini@crea.gov.it
} 
A first revision of all the modules was carried out by all the partners; a second revision was performed by 6 advisory board members chosen in the three countries among stakeholders of the wine sector. They had to evaluate the adequacy of the contents to the target audience. A final scientific revision was carried out by different specialists from France, Spain, Italy, USA and South Africa.

Table 1. Content of course modules.

\begin{tabular}{|c|c|}
\hline $\begin{array}{c}\text { Module } \\
\text { number }\end{array}$ & Content \\
\hline 1 & $\begin{array}{c}\text { Introduction to main virus diseases, and } \\
\text { their agronomic and economic impact }\end{array}$ \\
\hline 2 & Grapevine virus transmission \\
\hline 3 & $\begin{array}{r}\text { Detection methods available to identify } \\
\text { grapevine viruses }\end{array}$ \\
\hline 4 & $\begin{array}{c}\text { Control and the management of virus } \\
\text { diseases and their vectors }\end{array}$ \\
\hline 5 & New emerging viral diseases \\
\hline 6 & $\begin{array}{r}\text { Natural engineered resistance, tolerance } \\
\text { and cross protection }\end{array}$ \\
\hline
\end{tabular}

\subsection{Development of the e-learning platform and photogallery}

The draft versions of the e-learning were created using Microsoft PowerPoint software in each language and were then uploaded on the web platform. Courses were published using Forma.LMS, an open source and free Learning Management System by HORTA (spin off of Cattolica University). Modules and chapters are HTML5 multimedia objects compliant with the standard SCORM and compiled with Articulate Storyline. Supplementary materials, such as audios, videos, documents, glossary, photogallery, were added to improve the global richness of the course. The flow of navigation is sequential with restrictions driven by intra-module questions. A final test was set-up at the end of each module in order to assess the knowledge just acquired. Trainees who reach $75 \%$ of correct answers had access to the next module.

An interactive photo library with a keyword search engine was developed. With already more than 300 photos illustrating different symptoms of virus diseases onto multiple varieties, this application, in free access, is also downloadable on smartphones.

\subsection{Field session and evaluation of pilot courses}

In addition to the e-learning courses available on the platform, the training is completed with two practical sessions in field, one in spring and one in autumn. Once passed the theoretical part, successful trainees have access to the practical identification of grapevine virus disease symptoms in vineyard. A satisfaction questionnaire was provided to the students at the end of both e-learning and practical session to evaluate the pilot course.

\section{Results and Discussion}

Since the beginning, the interest in PAThOGEN project has been high (more than 300 pre-registered). Thus, for the pilot course, groups of "student-testers" were selected in the 3 countries trainees to represent the different professional categories of the wine sector: technicians, winegrowers, nurserymen, students, teachers, researchers, phytosanitary official services (Figure 1).

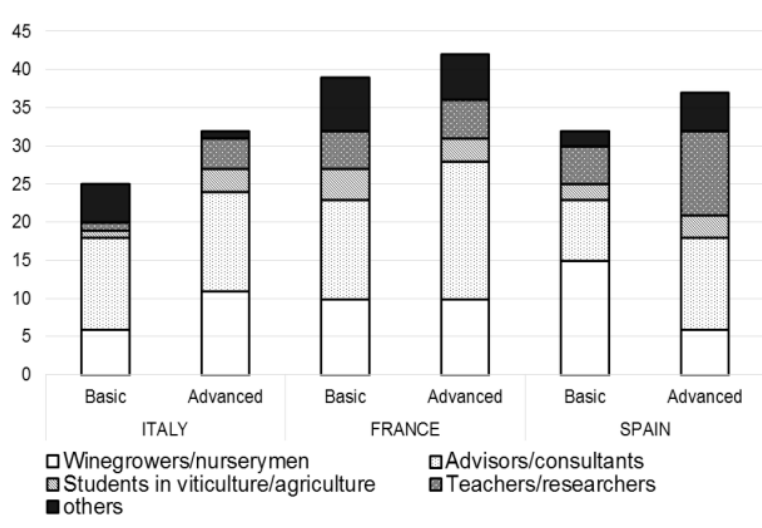

Fig. 1. Number and professional categories of trainees in the pilot courses for each country.

Overall, 128 people have tested the online courses and were invited to complete a satisfaction questionnaire. The satisfaction questionnaires showed a very good response of students to the e-learning pilot course in terms of contents, interest and achievement of the expectations. In each country and for both basic and advanced levels, the average response was over 4 out of 5 (very good). Among the 121 people who replied, a very large majority (98\%) considered the PAThOGEN program as an "interesting" or "very interesting" training program. The detailed evaluations allowed us to rework the courses both in terms of content (i.e. simplification, clarity of information) and functionality of the platform (i.e. speed of animations, quality of audio, sharpness of photos). We have therefore improved the 8 versions of the courses (4 languages, 2 levels) taking these remarks into account.

To complete the theoretical training, two field sessions to apply the acquired knowledge in practice were organized during the project in the 3 partner countries, and evaluated in the same way by the testers. The field session was crucial to finalize the training and was well appreciated by students (60\% find it excellent and $40 \%$ good) because it allowed them to identify the symptoms of virus diseases in vivo.

The costs of the online e-learning courses are the same in all countries and languages: $110 €$ per person for the basic level, and $200 €$ per person for the advanced level. The costs of the field sessions can differ among countries and depends on the number of participants per session, thus a quotation must be asked by mail to the country reference person listed in the web site www.pathogenproject.eu. 


\section{Conclusion}

During the project, we havedeveloped a mixed training (elearning and field sessions) for professionals in the wine sector, in order to improve their knowledge for the management of viral diseases. The project partners are now deploying this training in order to disseminate knowledge on grapevine viruses in each participating country and beyond. Several contacts have already requested that the training be adapted to their language (Greek and Portuguese for example). The e-learning training is already available in the four languages of the project (English, French, Spanish and Italian) and the field training is organized annually in France, Italy and Spain, except during the COVID-19 pandemic. More information can be found in the project website: www.pathogen-project.eu.

This project was Co-funded by the Erasmus+ Program of the European Union (2015-1FR1-KA202-015329). We gratefully thank Pietersen G., Martelli G.P., Fuchs M., Esmenjaud D., Herrbach E., Olmos A., Claverie M., Uriel G., Zekri O., Borgo M., Crespan M., Pecile M., for their suggestions, comments and photos.

\section{References}

1. O.I.V. International Organisation of Vine and Wine, https://www.oiv.int/public/medias/6782/oiv-2019statistical-report-on-world-vitiviniculture.pdf (2019)

2. F. Mannini, M. Digiaro, In B. Meng et al. (eds), Grapevine Viruses: Molecular Biology, Diagnostics and Management (Springer International Publishing AG, 2018, 453-482)

3. V.I. Maliogka, G.P. Martelli, M. Fuchs, N.I. Katis, Adv. Virus Res. 91, 175-227 (2015) 